\title{
Application of calcium oxide as heterogeneous catalyst for ethylic transesterification of residual frying soybean oil
}

\author{
Aplicação do óxido de cálcio como catalisador heterogêneo para a \\ transesterificação etílica de óleo de soja residual de fritura
}

\author{
Djonathan Luiz Giordani Lenz' \\ Pedro Vinnicius Caitano Guimarães" \\ Liziara da Costa Cabrera"I \\ Jonas Simon Dugatto'v \\ Bruno München Wenzelv
}

\begin{abstract}
Biodiesel can be produced through the transesterification reaction of a short-chain alcohol with a triacylglycerol, that can be obtained from vegetable oils or animal fats, in the presence of a catalyst. The use of ethanol as reactant is justified since its production is consolidated in Brazil. Among the heterogeneous catalysts, $\mathrm{CaO}$ shows potential in the transesterification reactions because it has a low cost, can be reused and is not corrosive. The recycling of frying oil for the production of biodiesel represents an alternative for the disposal of a waste and does not compete with the food industry. The residual oil and $\mathrm{CaO}$ were subjected to a pretreatment before the transesterification reactions. A Box-Behnken experimental design was applied with 3 factors: temperature, ethanol:oil molar ratio and reaction time. The reactions were carried out in a batch reactor, in which oil, ethanol and the catalyst were added. The samples were vacuum filtered and conducted to a rotary evaporator, in order to remove excess ethanol. The resulting mixture was centrifuged and, subsequently, a sample was collected from the supernatant phase. The yield was determined by a mass balance based in the concentrations of acylglycerols, that were determined through an HPLC-UV methodology. A second-order linear regression model was built and validated through statistic tests with a $5 \%$ significance level. The optimized operational parameters are $15: 1$ ethanol:oil molar ratio, $81.2^{\circ} \mathrm{C}$ e $6 \mathrm{~h}$ of reaction. From the obtained results it can be inferred that it is feasible to use residual frying oil as raw material, ethanol as reactant and $\mathrm{CaO}$ as catalyst for the production of biodiesel.
\end{abstract}

Keywords: Biodiesel; Residual oil; Calcium oxide.

\section{Resumo}

O biodiesel pode ser obtido através da reação de transesterificação de um álcool de cadeia curta com um triacilglicerol, que pode ser obtido a partir de óleos vegetais ou gorduras animais na presença de um catalisador. A utilização de etanol como reagente justifica-se porque este tem sua produção consolidada no Brasil. Dentre os catalisadores heterogêneos, o $\mathrm{CaO}$ mostra potencial nas reações de transesterificação, pois apresenta baixo custo, pode ser reutilizado e não é corrosivo. A reciclagem do óleo de fritura para a produção de biodiesel representa uma alternativa de destinação de um resíduo e não compete com o mercado 
alimentício. O óleo residual e o $\mathrm{CaO}$ passaram por pré-tratamento antes das reações de transesterificação. Foi aplicado um delineamento experimental Box-Behnken de 3 fatores: temperatura, razão molar etanol:óleo e tempo de reação. As reações foram conduzidas em um reator batelada, em que foram adicionados óleo, etanol e catalisador. As amostras foram filtradas à vácuo e conduzidas a um evaporador rotativo, para remoção do etanol excedente. A mistura resultante foi centrifugada e posteriormente retirada uma amostra da fase sobrenadante. O rendimento foi determinado a partir de um balanço de massa, baseado nas concentrações de acilgliceróis, que foram determiadas através de uma metodologia em HPLC-UV. Um modelo de regressão linear de segunda ordem foi construído e validado através de testes estatísticos com nível de significância de 5\%. Os parâmetros operacionais otimizados são razão molar etanol:óleo $15: 1,81,2{ }^{\circ} \mathrm{C}$ e 6 h de reação. A partir dos resultados obtidos infere-se que é viável a utilização do óleo residual de fritura como matéria-prima, etanol como reagente e $\mathrm{CaO}$ como catalisador para a produção de biodiesel.

Palavras-Chave: Biodiesel; Óleo residual; Óxido de cálcio.

\section{Introduction}

Considering that the non-renewable energy resources, such as oil, are limited, the search for alternative energy sources has been intensified over the last few years. Within this context, the processing of oils and fats converted into mono-alkyl esters (biodiesel) becomes an alternative, that can be used in diesel engines, by replacing or being added to mineral diesel.

The biodiesel is produced through the transesterification reaction of a short-chain alcohol with a triacylglycerol in the presence of a catalyst, and presents advantages when compared to mineral diesel, such as renewability, biodegradability, lower toxicity, higher combustion efficiency, higher cetane number, higher flash point, better lubrication, and reduced levels of particulates, carbon monoxide, total hydrocarbons and other toxic pollutants with local effects, that impact public health (CHEUNG et al, 2009; GUIMARÃES, 2004; JAMIL et al., 2018; WANG et al., 2000; YU et al., 2014).

The alcohol used in the transesterification reactions is usually methanol or ethanol (HAJÉK et al., 2012). Typically, methanol is used as reactant for the transesterification reactions, due to its greater reactivity and the lower temperatures and residence times demanded in the reactor. However, the use of ethanol has some advantages such as lower toxicity and production of a fuel with higher cetane number and better lubricity (LÔBO; FERREIRA; DA CRUZ, 2009). The use of ethanol as reactant is also justified because it has its production consolidated in Brazil, where the sugar cane products represent $16 \%$ of the 
national energy supply, with a production of 750 million tons of sugar cane per year (SOUZA et al., 2018).

Catalysts are essential to accelerate the conversion and can be homogeneous or heterogeneous, divided in three categories: basic, acidic and enzymatic (TALHA; SULAIMAN, 2016). The most used catalysts are homogeneous, namely solutions of $\mathrm{NaOH}, \mathrm{KOH}, \mathrm{HCl}$ and $\mathrm{H} 2 \mathrm{SO} 4$, however, due to environmental issues such as lower generation of effluents by the elimination of a washing step, these have been replaced by heterogeneous catalysts, which are more easily separated after the reaction and can be recovered for reuse (SOLTANI et al., 2017). Furthermore, heterogeneous catalysts have less corrosivity and reduced process costs (KIRUBAKARAN; SELVAN, 2018). Among these catalysts, CaO shows potential in the transesterification, since it has a low cost, can be reused and is not corrosive (BOEY; MANIAM; HAMID, 2011). One of the main sources of $\mathrm{CaO}$ is limestone, but it can also be obtained from calcium carbonate residues, such as clam shells and eggshell (COLOMBO, 2013).

For a greater development in the renewable energy resources field, the existence of a government incentive is important, enabling an adequate transition from fossil resources to sustainable energy systems. In 2004, the Federal Government of Brazil launched the National Program of Production and Use of Biodiesel (PNPB), with the aim of introduce biodiesel in the Brazilian energy matrix. The main result of the first phase was the definition of a definition of a legal and regulatory framework (ANP, 2016). In Brazil, there is an expectation that the country becomes of the main producers and consumers of biodiesel, due to the agricultural cultivation of the several sources of raw materials that can be used for the production of these fuels.

The most abundant and used raw material for the production of biodiesel in Brazil is soybean oil, but one of its limitations is the competition with the food industry. According to MOFIJUR et al. (2013), in the world, approximately $95 \%$ of the biodiesel is produced from edible oils, however, the competitiveness with the food industry ends up generating a global imbalance in the market demand and supply, causing a reduction of the sources and an 
increase in the costs of these raw materials, thus, demanding investments in switching production to non-edible oils.

The price reduction of the raw materials is studied through researches and development of projects with less noble raw materials that, even so, can present high biodiesel conversion efficiencies. According to DIB (2010), cheap raw materials like residual oils and fats have drawn attention of biodiesel producers due to its low cost. The recycling of frying oil for biodiesel production would not only remove an undesired material from the environment, but would also allow the generation of an alternative, renewable and cleaner energy source, thus, presenting a strong environmental appeal. The residual oils and fats may come from snack bars and industrial kitchens, enterprises where there is a frying process of food products and the generation of residues. As reported by CHRISTOFF (2006), most of these residues are incorrectly disposed in the sewer network. The low solubility of vegetable oils in water becomes a negative factor, impairing its degradation in sewage treatment plants by biological processes and causing problem in the public supply water treatment systems. Therefore, allocating this residue in the production of biodiesel would be an environmentally viable alternative.

Several researchers have been investigating the production of biodiesel with residual oils. PIKER et al. (2016) achieved a yield of $97 \%$ using methanol as reactant (6:1 molar ration) and $\mathrm{CaO}$ obtained from chicken eggshell (5.8 wt\%) in $11 \mathrm{~h}$ reaction time and environment temperature. JOSHI et al. (2017) reported a yield of $88 \%$ in $30 \mathrm{~min}$ at $50{ }^{\circ} \mathrm{C}$, using methanol (10:1 molar ratio) and $\mathrm{CaO}(1 \mathrm{wt} \%)$, with the aid of a high speed homogenizer. CHEN, LIN and CHEN (2017) observed a yield of $95.8 \%$ in $1 \mathrm{~h}$ at $60^{\circ} \mathrm{C}$, using methanol (20:1 molar ratio) and $\mathrm{Li}_{2} \mathrm{SO}_{3}$ (2 wt\%). CHRISTOFF (2006) achieved a yield of $84 \%$ in $1 \mathrm{~h}$ with temperature between 40 and $55^{\circ} \mathrm{C}$, using ethanol (12:1 molar ratio) and $\mathrm{NaOH}(0.5 \mathrm{wt} \%)$. The high yield values obtained using this raw material of lower added value enables a considerable economic and environmental advantage in face of the fuel produced with refined oils.

The aim of this study was to assess the technical viability of biodiesel production through the transesterification reaction, using residual frying soybean oil as raw material, ethanol as reactant and $\mathrm{CaO}$ as catalyst, as well as to investigate the applicability of the 
catalyst and the influence of the operational parameters (temperature, ethanol:oil molar ratio and reaction time) on the process.

\section{Material and Methods}

A residual frying soybean oil sample was collected from a household in Cerro Largo, RS, Brazil. Before the transesterification reactions, a pre-treatment was applied, in which the suspended particles where removed by vacuum filtration with a filter paper (4-7 $\mu \mathrm{m}$ particles retention) and the oil was heated at $120^{\circ} \mathrm{C}$ for $90 \mathrm{~min}$ in a drying oven in order to remove the residual water. The pre-treated oil (Figure 1) was transferred to a glass container, covered with plastic film and aluminum foil and stored in the absence of light.

Figure 1 - Residual frying soybean oil after pre-treatment

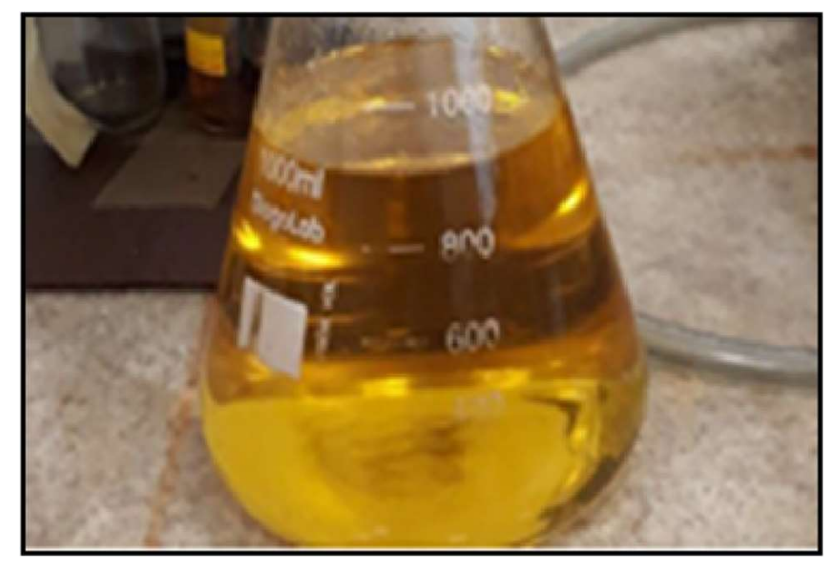

The $\mathrm{CaO}(95 \%$ purity) used in the reactions was pre-treated to avoid contamination with $\mathrm{CO}_{2}$ and water. Initially, it was taken to a drying oven at $120^{\circ} \mathrm{C}$ for $12 \mathrm{~h}$, then, transferred to a muffle furnace for calcination and activation at $550{ }^{\circ} \mathrm{C}$ for $5.5 \mathrm{~h}$.

The effects of the different operational parameters in the yield of the transesterification reaction were investigated using a 3-factor Box-Behnken experimental design (BOX; BEHNKEN, 1960), including temperature, ethanol:oil molar ratio and reaction time, as presented in Table 2. The experiments at the central point were performed in triplicate.

Table 1 - Residual frying soybean oil after pre-treatment 


\begin{tabular}{lccc} 
& -1 & 0 & +1 \\
\hline Temperature $\left(\mathrm{X}_{1}\right)$ & $60{ }^{\circ} \mathrm{C}$ & $75{ }^{\circ} \mathrm{C}$ & $90{ }^{\circ} \mathrm{C}$ \\
Molar ratio $\left(\mathrm{X}_{2}\right)$ & $15: 1$ & $21: 1$ & $27: 1$ \\
Reaction time $\left(\mathrm{X}_{3}\right)$ & $2 \mathrm{~h}$ & $4 \mathrm{~h}$ & $6 \mathrm{~h}$ \\
\hline
\end{tabular}

The transesterification reactions were carried out in a batch reactor, composed of a 500-mL round-bottom volumetric flask equipped with a Graham condenser. This system was designed to form a water-cooled reflux system and avoid ethanol losses. $30 \mathrm{~g}$ of oil, a catalytic mixture (ethanol at the adequate molar ratio and $5 \%$ of the catalyst, in relation to the weight of oil) and a magnetic stir bar were added to the flask. The flask was immersed in and oil bath, with controlled temperature by a heating plate, under stirring. This process is showed in Figure 2.

Figure 2 - Experimental procedure: (a) catalytic mixture and (b) batch reactor

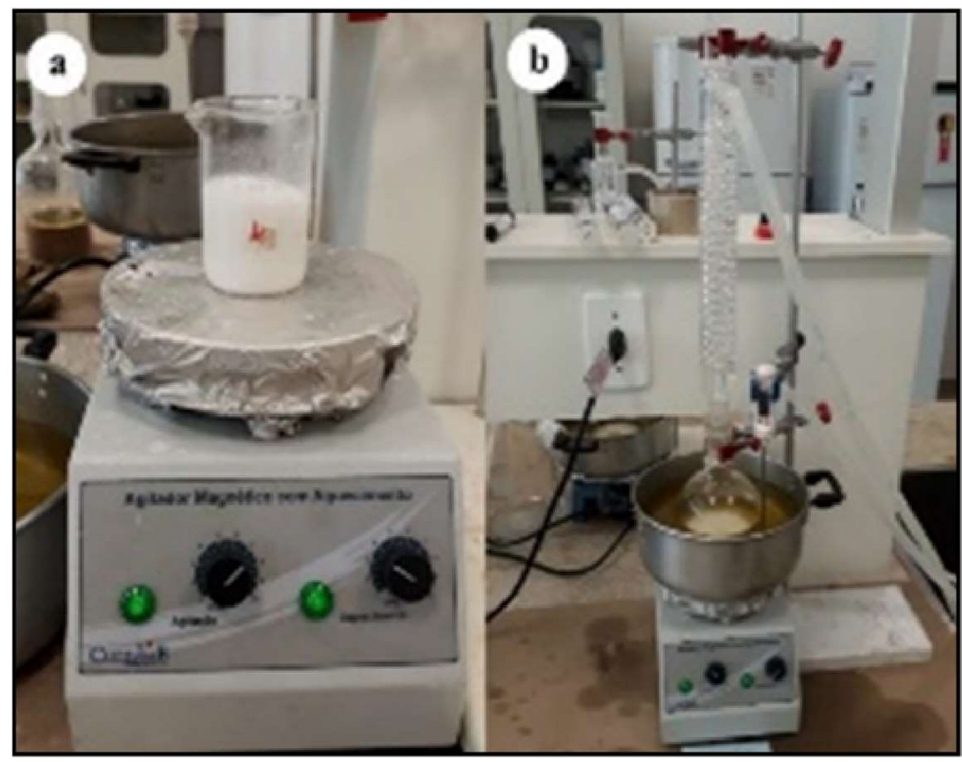

The samples obtained from the experimental runs were vacuum filtered for removal of the catalyst. The excess of ethanol was removed by rotary evaporation. The resulting mixture was stored in an Ambar flask under refrigeration until the chromatographic analysis.

The concentrations of acylglycerols were determined through an adaptation the methodology described by DI NICOLA et al. (2008) for characterization of biodiesel in HPLCUV. The specifications of the applied method are presented in Table 2.

Table 2 - Chromatographic method applied in the acylglycerols quantification 


\section{Specifications:}

Chromatographic column: NST C18, $250 \mathrm{~mm} \times 4.6 \mathrm{~mm} \times 5 \mu \mathrm{m}$

Injection volume: $20 \mu \mathrm{L}$

Eluent flow: $1 \mathrm{~mL} \mathrm{min-1}$

Oven temperature: $45^{\circ} \mathrm{C}$

Detector: UV-vis with photodiode array (PDA)

Analyzed wavelength: $205 \mathrm{~nm}$

\begin{tabular}{ccc}
\hline $\begin{array}{c}\text { Gradient: } \\
\text { Time (min) }\end{array}$ & $\begin{array}{c}\text { Mobile phase A } \\
\text { Acetonitrile:Methanol 4:1 (v/v) }\end{array}$ & $\begin{array}{c}\text { Mobile phase B } \\
\text { N-Hexane:Isopropanol 8:5 (v/v) }\end{array}$ \\
\hline 0.01 & $100 \%$ & $0 \%$ \\
5.20 & $90 \%$ & $10 \%$ \\
16.00 & $34 \%$ & $66 \%$ \\
20.00 & $34 \%$ & $66 \%$ \\
22.00 & $100 \%$ & $0 \%$ \\
22.01 & $100 \%$ & $0 \%$ \\
\hline
\end{tabular}

A stock solution with $2000 \mathrm{mg} \mathrm{L}^{-1}$ of each component was prepared from a standard solution of acylglycerols (Supelco 1787-1AMP), containing $10 \mathrm{mg}$ of monoolein, $10 \mathrm{mg}$ of 1,2-diolein, $10 \mathrm{mg}$ of 1,3-diolein and $10 \mathrm{mg}$ of triolein, and dissolved in the mobile phase $\mathrm{B}$. Dilutions between 2 and $750 \mathrm{mg} \mathrm{L}^{-1}$ were prepared from the stock solution and injected in duplicate (an example of the obtained chromatogram is presented in Figure 3). The association between the retention time $\left(t_{R}\right)$ with the respective molecule was made from a characteristic of liquid chromatography in C18 column, where the elution order is directly related to the effective carbon number $(E C N)$, thus, the $t_{R}$ presents the following order: monoolein < diolein < triolein (ANDRADE; MAZZEI; D'ÁVILA, 2011; DI NICOLA et al., 2008; HOLČAPEK et al., 1999).

Figure 3 - Chromatogram obtained from the acylglycerol standard solution $\left(750 \mathrm{mg} \mathrm{L}^{-1}\right)$ 


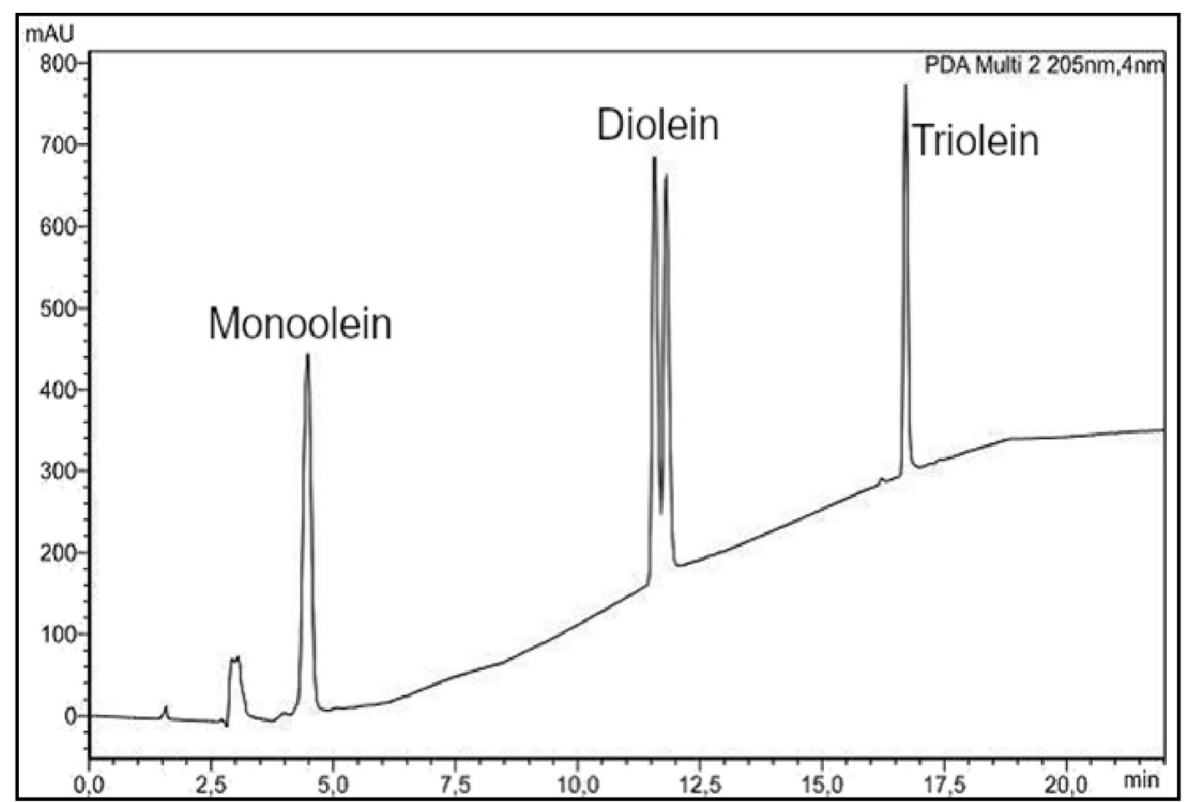

The $t_{R}$ for each component were determined by the chromatograms as follows: 4.4 min for monoolein, 11.5 and $11.7 \mathrm{~min}$ for the dioleins and $16.6 \mathrm{~min}$ for the triolein. A calibration curve was determined for each component by associating the areas of the chromatographic signals with the previously known concentrations.

The samples of the transesterification reactions were diluted in the mobile phase $B$, in order to obtain concentrations of $5000 \mathrm{mg} \mathrm{L}^{-1}$. A dilution of oil in the same concentration was prepared to represent the initial condition. The concentrations of acylglycerols were calculated from the areas of the chromatographic signals (Figure 4) and the calibration curves. The total concentration of diolein was considered as the sum of the concentrations of 1,2-diolein and 1,3-diolein. 
Figure 4 - Examples of experimental run chromatograms: (a) residual frying soybean oil; and (b) experimental design central point

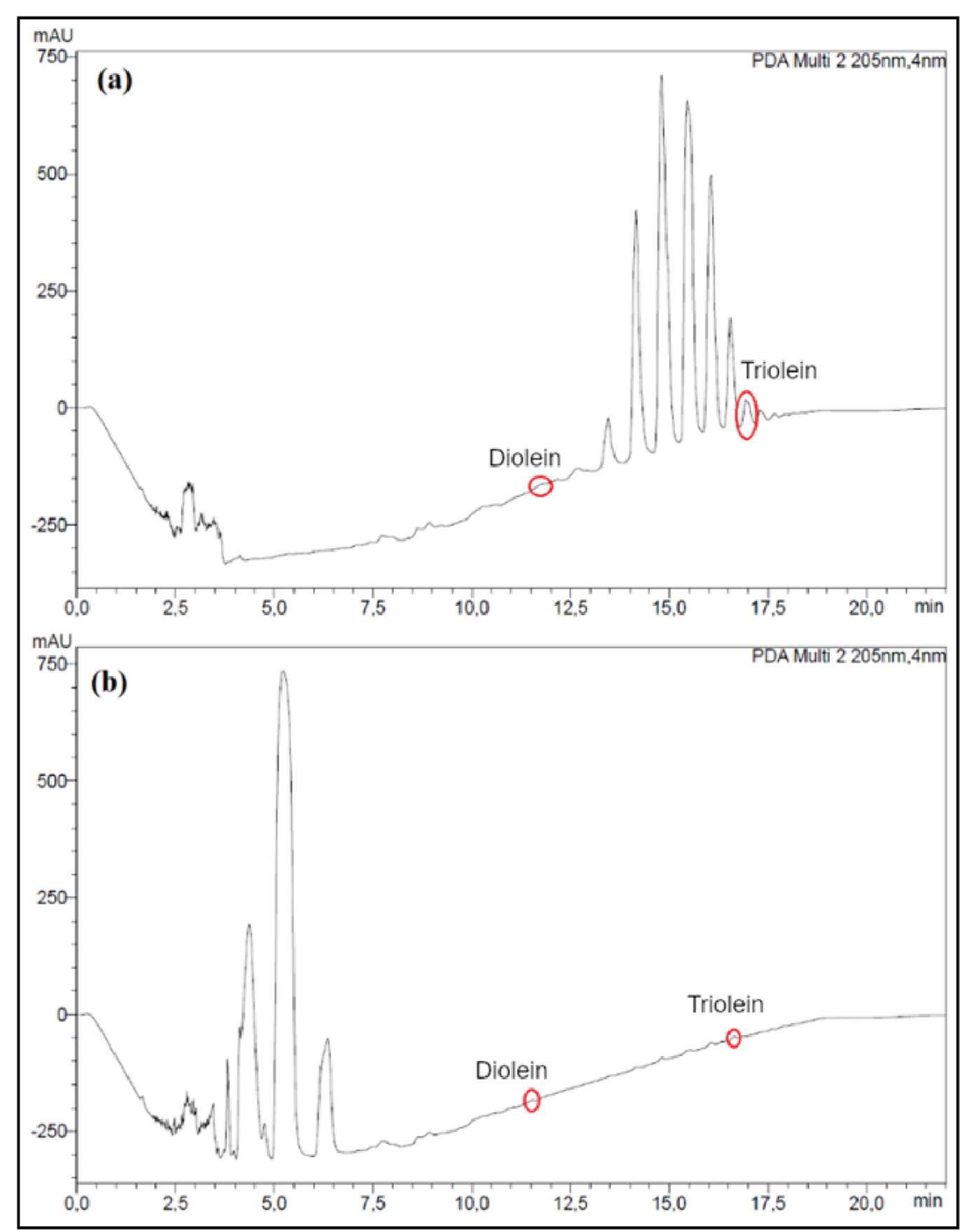

The yield of the reaction was calculated from the molar concentrations of acylglycerols, according to a mass balance performed in a batch reactor, as presented in Eq. 1.

$$
\text { Yield }=1-\frac{F_{m}\left(3 C_{T A G}+2 C_{D A G}+C_{M A G}\right)}{3 C_{T A G, 0}+2 C_{D A G, 0}+C_{M A G, 0}}
$$

Where $C_{i}$ is the final concentration, $C_{i, 0}$ is the initial concentration and $F_{m}=1.053$ represents the theoretical mass increase of the complete reaction. 
A second-order linear regression model was fitted to the experimental results, using the software Matlab ${ }^{\circledR}$, by the least squares method, allowing an analysis of both linear and quadratic effects, as shown in Eq. 2 (MONTGMOMERY, 2012).

$$
\hat{y}=\beta_{o}+\sum_{i=1}^{q} \beta_{i} X_{i}+\sum_{i=1}^{q} \sum_{j=1}^{q} \beta_{i, j} X_{i} X_{j}+\sum_{i=1}^{q} \beta_{i, i} X_{i}^{2}
$$

Where $\hat{y}$ is the dependent variable (yield), $\beta$ are the fittable parameters of the model, $X$ are the independent variables and $\mathrm{q}$ is the number of factors $(q=3)$.

The validation of the model was made by an analysis of variance (ANOVA) to verify the significance of the model, the significance of the regression and the lack of fit. All the statistical tests done with a $5 \%$ significance level. The coefficient of determination $\left(R^{2}\right)$ was calculated to evaluate the goodness-of-fit of the model to the experimental data, according to Eq. 3.

$$
R^{2}=1-\frac{R S S_{\text {mod }}}{S S_{\text {exp }}}=1-\frac{\sum\left(\text { yield }_{i, \bmod }-\text { yield }_{i, \exp }\right)^{2}}{\sum\left(\text { yield }_{i, \exp }-\overline{\text { yield }}_{i, \exp }\right)^{2}}
$$

Where $R S S_{\text {mod }}$ is the residual sum of squares of the experimental data versus model prediction and $S S_{\text {exp }}$ is the sum of squares of the experimental mean deviations.

\section{Results and Discussion}

A second-order linear model was proposed based on the experimental results, according to Eq. 2. In order to assess the effects of the factors and their interactions, Table 3 presents the results of the ANOVA, considering the coded values, maintaining only the parameters that are significant to the model. 
Table 3 - Analysis of variance (ANOVA) of the factors and their interactions

\begin{tabular}{cccccc}
\hline & Sum of squares & Degrees of freedom & F-value & p-value & Decision* $^{*}$ \\
\hline $\mathrm{X}_{1}$ & 0.070 & 1 & 2.514 & 0.254 & 0 \\
$\mathrm{X}_{2}$ & 0.006 & 1 & 0.199 & 0.699 & 0 \\
$\mathrm{X}_{3}$ & 0.483 & 1 & 17.460 & 0.053 & 1 \\
$\mathrm{X}_{1} \mathrm{X}_{2}$ & 0.101 & 1 & 3.649 & 0.196 & 1 \\
$\mathrm{X}_{1} \mathrm{X}_{3}$ & 0.001 & 1 & 0.028 & 0.883 & 0 \\
$\mathrm{X}_{2} \mathrm{X}_{3}$ & 0.007 & 1 & 0.239 & 0.673 & 0 \\
$\mathrm{X}_{1}{ }^{2}$ & 1.168 & 1 & 42.197 & 0.023 & 1 \\
$\mathrm{X}_{2}{ }^{2}$ & 1.226 & 1 & 44.291 & 0.022 & 1 \\
$\mathrm{X}_{3}{ }^{2}$ & 1.499 & 1 & 54.181 & 0.018 & 1 \\
Experimental error & 0.055 & 2 & 0 & 0 & 0 \\
\hline
\end{tabular}

${ }^{*} 0$ - Not incorporated in the model.

*1 - Incorporated in the model.

Firstly, the parameters that presented $p>0.05$ were considered non-significant and a F-test was performed do verify the significance of the regression. The regression could not be validated by removing these parameters, thus, other parameters were added, one by one, in ascending order in relation to the p-value, until a valid regression was obtained. The F-test applied to this regression resulted in the values of $F_{0}=9.62$ and $F_{t a b}=3.87$. Since $F_{0}>F_{t a b}$, the regression was considered significant. An equation for the yield was proposed from the parameters considered significant, as presented in Eq. 4, with R2 $=0.89$.

$$
\text { Yield }=0.64+0.25 X_{3}-0.22 X_{1} X_{2}-0.16 X_{1}{ }^{2}-0.14 X_{2}{ }^{2}-0.06 X_{3}{ }^{2}
$$

The experimental runs performed according to the experimental design, as well as the results obtained experimentally and the results predicted by the fitted model are presented in Table 4. 
Table 4 - Experimental and predicted results

\begin{tabular}{|c|c|c|c|c|c|c|c|c|}
\hline \multirow{2}{*}{$\mathbf{N}$} & \multicolumn{3}{|c|}{ Uncoded variables } & \multicolumn{3}{|c|}{ Coded variables } & \multirow{2}{*}{ Experimental yield (\%) } & \multirow{2}{*}{ Predicted yield (\%) } \\
\hline & $\mathrm{X} 1$ & $\mathrm{X} 2$ & $\mathrm{X} 3$ & $\mathrm{X} 1$ & $\mathrm{x} 2$ & X3 & & \\
\hline 1 & 60 & 15 & 4 & -1 & -1 & 0 & 6.6 & 11.6 \\
\hline 2 & 90 & 15 & 4 & 1 & -1 & 0 & 66.8 & 56.5 \\
\hline 3 & 60 & 27 & 4 & -1 & 1 & 0 & 46.3 & 56.5 \\
\hline 4 & 90 & 27 & 4 & 1 & 1 & 0 & 16.5 & 11.6 \\
\hline 5 & 60 & 21 & 2 & -1 & 0 & -1 & 8.9 & 17.8 \\
\hline 6 & 90 & 21 & 2 & 1 & 0 & -1 & 27.1 & 17.8 \\
\hline 7 & 60 & 21 & 6 & -1 & 0 & 1 & 53.7 & 66.9 \\
\hline 8 & 90 & 21 & 6 & 1 & 0 & 1 & 79.7 & 66.9 \\
\hline 9 & 75 & 15 & 2 & 0 & -1 & -1 & 27.8 & 19.6 \\
\hline 10 & 75 & 27 & 2 & 0 & 1 & -1 & 11.1 & 19.6 \\
\hline 11 & 75 & 15 & 6 & 0 & -1 & 1 & 65.8 & 68.8 \\
\hline 12 & 75 & 27 & 6 & 0 & 1 & 1 & 72.2 & 68.8 \\
\hline 13 & 75 & 21 & 4 & 0 & 0 & 0 & 63.9 & 63.4 \\
\hline
\end{tabular}

A lack of fit test, that compares the variance associated to the model with the experimental variance, was applied for validation of the model. The test resulted in values of $F_{0}=0.20$ and $F_{t a b}=9.35$. Since $F_{0}<F_{t a b}$, it was concluded that the model is significant for prediction of the reaction yield.

Figure 5(a) visually represents the correlation between the yield values obtained experimentally and those predicted by the model. The closer the point of the drawn diagonal line, the better is the model's ability to predict the evaluated experimental conditions. Figure $5(b)$ represents the correlation between the residues and the results predicted by the model. It can be visually verified that the residues are randomly located

Figure 5 - Graphical representation of the model goodness of fit. (a) experimental vs. predicted results; (b) residual plot 


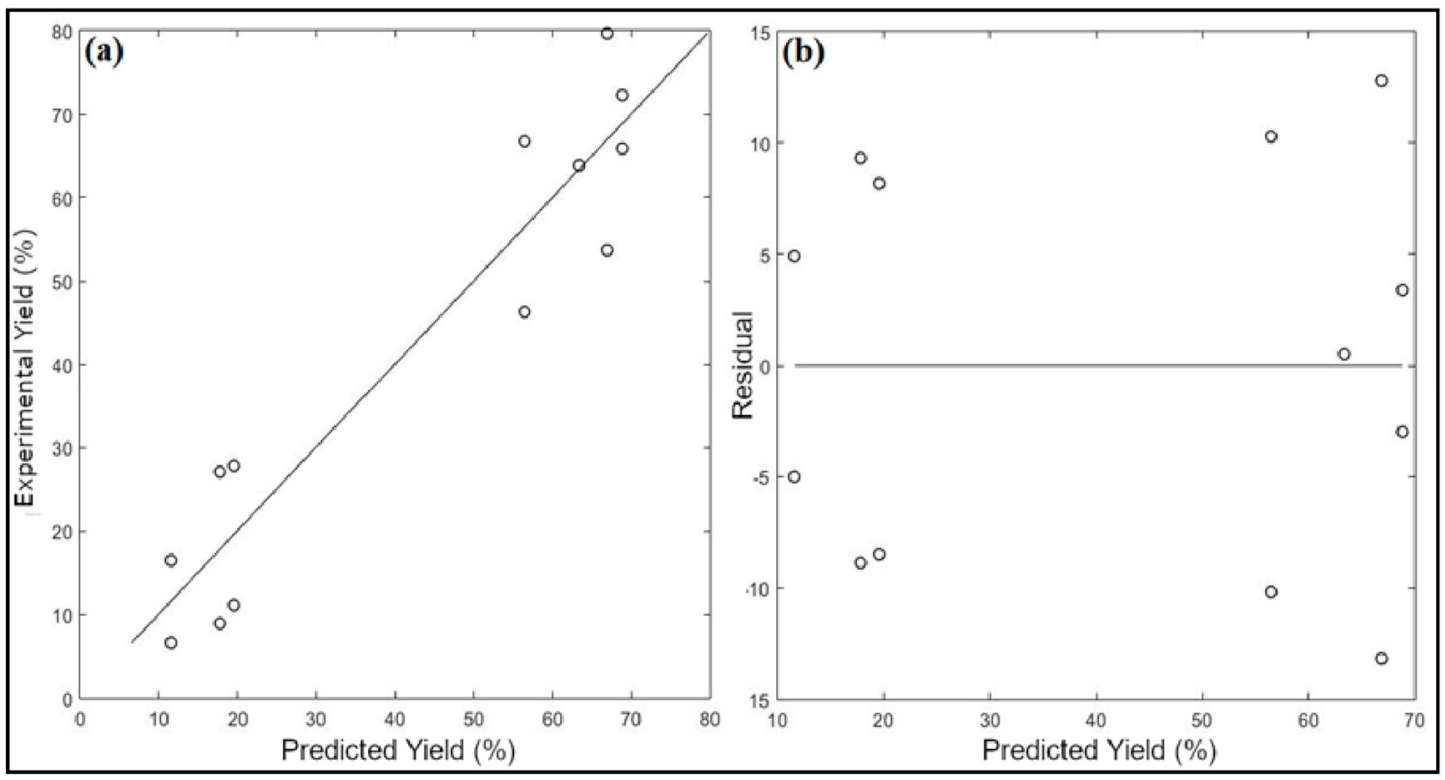

In order to graphically express the results, Figure 6 present response surfaces and contour plots, addressing the reaction yield as a function of the independent variables. 
Figure 6 - Response surfaces and contour plots correlating reaction yield with (a) ethanol: oil molar ratio and temperature, with reaction time fixed at the central value; (b) reaction time and temperature, with ethanol: oil molar ratio fixed at the central value; (c) reaction time and ethanol: oil molar ratio, with temperature fixed at the central value

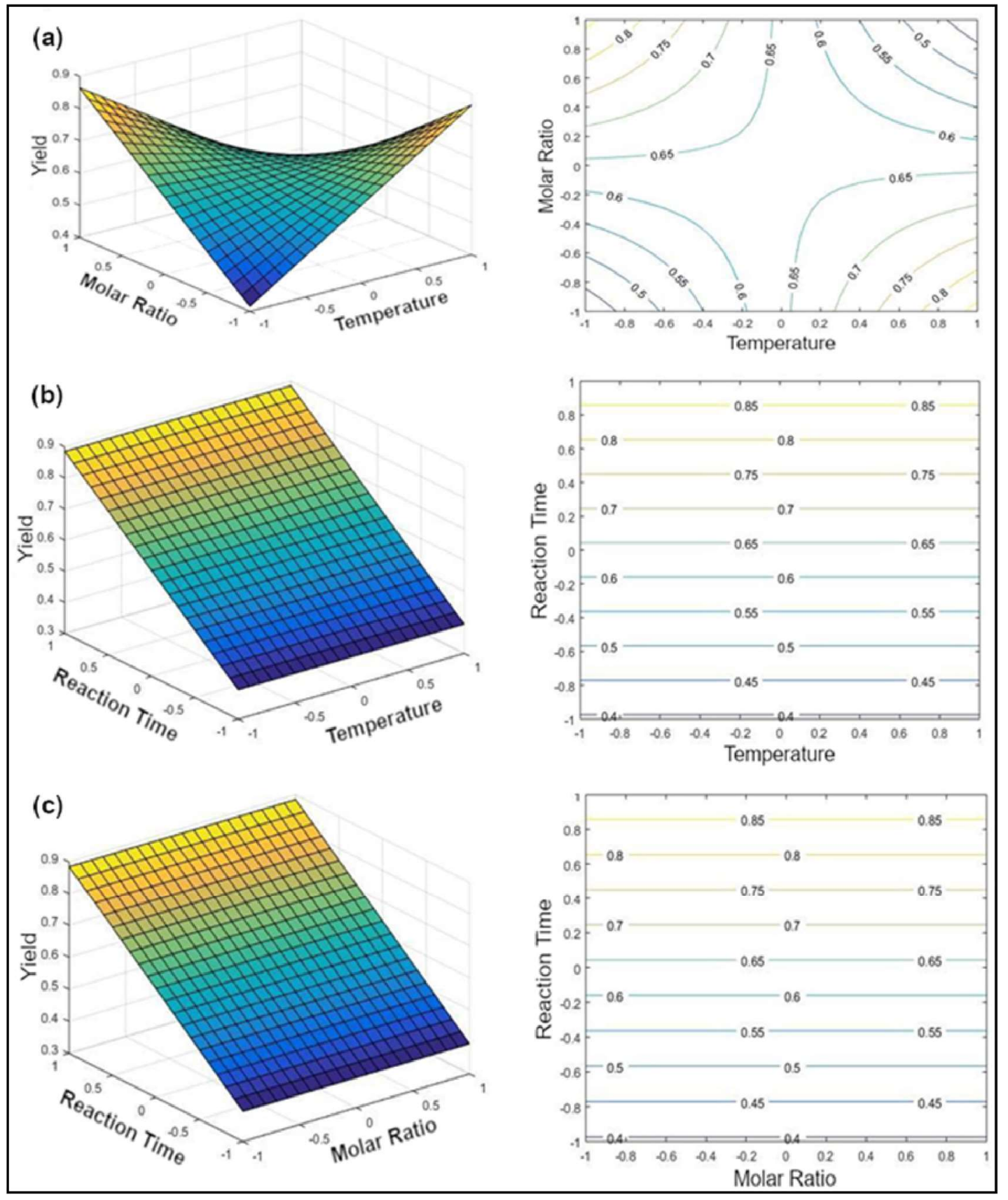

Based on the model, the maximum predicted yield is $100 \%$, with the following operational conditions: $15: 1$ ethanol:oil molar ratio, $81.2^{\circ} \mathrm{C}$ for $6 \mathrm{~h}$.

The stoichiometry of the transesterification reaction indicates the necessity of $3 \mathrm{~mol}$ of alcohol for each mol of triacylglycerol, however, the application of excess alcohol 
dislocates the reaction balance in the direction of biodiesel formation. The reduction in the yield from a certain point of excess alcohol was reported in several studies. One of the possibilities is that the yield decreases due to the dissolution of glycerol in the excess alcohol, which inhibits the reaction (HANH et al., 2007; LATCHUBUGATA et al., 2018; LIMA et al., 2010; MORAIS et al., 2013; ROOSTA; SABZPOOSHAN, 2016).

The temperature is an influent parameter in the transesterification reaction yield, since an increase in the temperature increases the movement of the particles and the solubility of the reactants and, for homogeneous catalysts, the it also affects the catalytic activity (SOLTANI et al., 2017). The determined optimal temperature value was not the highest applied in the experimental design, but $81.2^{\circ} \mathrm{C}$, which is very close to the boiling point of ethanol $\left(78.4^{\circ} \mathrm{C}\right)$. According to LATCHUBUGATA et al. (2018), temperatures much higher than the boiling point of the alcohol represent larger portions of the alcohol in vapor form, which reduces its availability in the liquid form and results in lower yield values.

\section{Conclusion}

From the obtained results it can inferred that the use of residual frying oil as a raw material is viable, with the appropriate pre-treatment steps, for the production of biodiesel, considering that this material has low added value, since it is a residue. $\mathrm{CaO}$ showed to be an efficient and low-cost catalyst for the process. It is important to highlight that the steps of thermal pre-treatment of $\mathrm{CaO}$ are essential to the process, allowing the activation of the catalyst. The experimental results allowed to fit a second-order linear model, with a considerable prediction capacity $\left(R^{2}=0,89\right)$, within the interval used for the factors. The optimized operational conditions were estimated as 15:1 ethanol:oil molar ratio, temperature of $81.2^{\circ} \mathrm{C}$ and $6 \mathrm{~h}$ of reaction. Researches in the renewable fuels field should be encouraged and acknowledged through public policies and government measures. This would result in a greater adaptation capacity of the energy matrix, since fossil fuels, besides being non-renewable, cause several environmental impacts.

\section{Acknowledgments}


The authors are very grateful to Universidade Federal da Fronteira Sul (UFFS) and Coordenação de Aperfeiçoamento de Pessoal de Nível Superior (CAPES) for the granted support and funding.

\section{References}

ANDRADE, D. F.; MAZZEI, J. L.; D'AVILA, L. A. Separation of acylglycerols from biodiesel by high performance liquid chromatography and solid-phase extraction. Revista Virtual de Química, v. 3, p. 452-466, http://dx.doi.org/10.5935/1984-6835.20110050, 2011.

ANP, Ministério de Minas e Energia. Biodiesel. 2016 Aug 16 [cited 2020 May 12]. Available from: http://www.anp.gov.br/biocombustiveis/biodiesel.

BOEY, P. L.; MANIAM, G. P.; HAMID, S. A. Performance of calcium oxide as a heterogeneous catalyst in biodiesel. Chemical Engineering Journal, v. 168, p. 15-22, https://doi.org/10.1016/j.cej.2011.01.009, 2011.

BOX, G. E. P.; BEHNKEN, D. W. A class of second order rotatable designs derivable from those of first order. Annals of Mathematical Statistics, v. 31, p. 838-864, https://doi.org/10.1214/aoms/1177705661, 1960.

CHEN, Y. C.; LIN, D. Y; CHEN, B. H. Transesterification of acid soybean oil for biodiesel production using lithium metasilicate catalyst prepared from diatomite. Journal of the Taiwan Institute of Chemical Engineers, v. 79, p. 31-36, https://doi.org/10.1016/j.jtice.2017.05.001, 2017.

CHEUNG, K. L.; POLIDORI, A.; NTZIACHRISTOS, L.; TZAMKIOZIS, T.; SAMARAS, Z.; CASSEE, F. R.; GERLOFS, M.; SIOUTAS, C. Chemical characteristics and oxidative potential of particulate matter emissions from gasoline, diesel, and biodiesel cars. Environmental Science and Technology, v. 43, p. 6334-6340, https://doi.org/10.1021/es900819t, 2009.

CHRISTOFF, P. Produção de biodiesel a partir do óleo residual de fritura comercial. Estudo de caso: Guaratuba, Litoral Paranaense [dissertaton]. Curitiba: LACTEC, p. 82, http://sistemas.institutoslactec.org.br/mestrado/dissertacoes/arquivos/paulochristoff.pdf, 2006

COLOMBO, K. Produção de biodiesel por transesterificação com catálise heterogênea utilizando $\mathrm{CaO}$ como catalisador [dissertation]. Blumenau: Centro de Ciências Tecnológicas/FURB, p. 179, https://bu.furb.br/consulta/novaConsulta/recuperaMfnCompleto.php?menu=esconde\&Cd MFN=352882, 2013. 
DI NICOLA, G.; PACETTI, M.; POLONARA, F.; SANTORI, G.; STRYJEK R. Development and optimization of a method for analyzing biodiesel mixtures with non-aqueous reversed phase liquid chromatography. Journal of Chromatography A, v. 1190, p. 120-126, https://doi.org/10.1016/j.chroma.2008.02.085, 2008.

DIB, F. H. Produção de biodiesel a partir de óleo residual reciclado e realização de testes comparativos com outros tipos de biodiesel e proporções de mistura em um moto-gerador [dissertation]. Ilha Solteira: Faculdade de Engenharia de Ilha Solteira/UNESP, p. 144, https://repositorio.unesp.br/handle/11449/88869, 2010.

GUIMARÃES, J. R. P. de F. Toxicologia das emissões veiculares de diesel : um problema de saúde ocupacional e pública. Revista de Estudos Ambientais, v. 6, p. 82-94, 2004.

HAJÉK, M.; SKOPAL, F.; ČAPEK, L.; ČERNOCH, M.; KUTÁLEK, P. Ethanolysis of rapeseed oil by $\mathrm{KOH}$ as homogeneous and as heterogeneous catalyst supported on alumina and $\mathrm{CaO}$. Energy, v. 48, p. 392-397, https://doi.org/10.1016/j.energy.2012.06.052, 2012.

HANH, H. D.; DONG, N. T.; OKITSU, K.; MAEDA, Y.; NISHIMURA, R. Effects of molar ratio, catalyst concentration and temperature on transesterification of triolein with ethanol under ultrasonic iradiation. Journal of the Japan Petroleum Institute, v. 50, p. 195-199, https://doi.org/10.1627/jpi.50.195, 2007.

HOLČAPEK, M.; JANDERA, P.; FISCHER, J.; PROKEŠ, B. Analytical monitoring of the production of biodiesel by high-performance liquid chromatography with various detection methods. Journal of Chromatography A, v. 858, p. 13-31, https://doi.org/10.1016/S00219673(99)00790-6, 1999.

JAMIL, F.; AL-HAJ, L.; AL-MUHTASEB, A. H.; AL-HINAI, M. A.; BAAWAIN, M.; RASHID, U.; AHMAD, M. N. M. Current scenario of catalysts for biodiesel production: A critical review. Reviews in Chemical Engineering, v. 34, p. 267-297, https://doi.org/10.1515/revce-20160026, 2018.

JOSHI, S.; GOGATE, P. R.; MOREIRA JR, P. F.; GIUDICI, R. Intensification of Biodiesel production from soybean oil and waste cooking oil in the presence of heterogeneous catalyst using high speed homogenizer. Ultrasonics Sonochemistry, v. 39, p. 645-653, https://doi.org/10.1016/j.ultsonch.2017.05.029, 2017.

KIRUBAKARAN, M.; SELVAN, V. A. M. A comprehensive review of low cost biodiesel production from waste chicken fat. Renewable and Sustainable Energy Reviews, v. 82, p. 390401, https://doi.org/10.1016/j.rser.2017.09.039, 2018.

LATCHUBUGATA, C. S.; KONDAPANENI, R. V.; PATLURI, K. K.; VIRENDRA, U.; VEDANTAM, S. Kinetics and optimization studies using Response Surface Methodology in biodiesel production using heterogeneous catalyst. Chemical Engineering Research and Design, v. 135, p. 129-39, https://doi.org/10.1016/j.cherd.2018.05.022, 2018. 
LIMA, A. L.; LIMA, A. P.; PORTELA, F. M.; SANTOS, D. Q.; NETO, W. B.; HERNÁNDEZ-TERRONES, M. G.; FABRIS, J. D. Parâmetros da reação de transesterificação etílica com óleo de milho para produção de biodiesel. Eclética Química, v. 35, p. 101-106, http://dx.doi.org/10.1590/S0100-46702010000400013, 2010.

LÔBO, I. P.; FERREIRA S. L. C.; DA CRUZ, R. S. Biodiesel: Parâmetros de qualidade e métodos analíticos. Química Nova, v. 32, p. 1596-1608, http://dx.doi.org/10.1590/S010040422009000600044, 2009.

MOFIJUR, M.; MASJUKI, H. H.; KALAM, M. A.; ATABANI, A.E.; SHAHABUDDIN, M.; PALASH, S. M.; HAZRAT, M. A. Effect of biodiesel from various feedstocks on combustion characteristics, engine durability and materials compatibility: A review. Renewable and Sustainable Energy Reviews, v. 28, p. 441-455, https://doi.org/10.1016/j.rser.2013.07.051, 2013.

MONTGOMERY, D. C. Design and analysis of experiments. 8th ed. Tempe: John Wiley \& Sons; 2012.

MORAIS, F. R.; LOPES, C. S.; LIMA NETO, E. G.; RAMOS, A. L. D.; DA SILVA, G. F. Influência da Temperatura e da Razão Molar na Produção Contínua de Biodiesel. Scientia Plena, v. 9, p. 104-202, 2013.

PIKER, A.; TABAH, B.; PERKAS, N.; GEDANKEN, A. A green and low-cost room temperature biodiesel production method from waste oil using egg shells as catalyst. Fuel, v. 182, p.3441, https://doi.org/10.1016/j.fuel.2016.05.078, 2016.

ROOSTA, A.; SABZPOONSHAN, I. Modeling the effects of cosolvents on biodiesel production. Fuel, v. 186, p. 779-786, https://doi.org/10.1016/j.fuel.2016.09.037, 2016.

SOLTANI, S.; RASHID, U.; AL-RESAYES, S. I.; NEHDI, I. A. Recent progress in synthesis and surface functionalization of mesoporous acidic heterogeneous catalysts for esterification of free fatty acid feedstocks: A review. Energy Conversion and Management, v. 141, p. 183-205, https://doi.org/10.1016/j.enconman.2016.07.042, 2017.

SOUZA, S. P.; NOGUEIRA, L. A. H.; MARTINEZ, J.; CORTEZ, L. A. B. Sugarcane can afford a cleaner energy profile in Latin America \& Caribbean. Renewable Energy, v. 121, p. 164-172, https://doi.org/10.1016/j.renene.2018.01.024, 2018.

TALHA, N. S.; SULAIMAN, S. Overview of Catalysts in Biodiesel Production. ARPN Journal of Engineering and Applied Sciences, v. 11, p. 439-448, http://www.arpnjournals.com/, 2016.

WANG, W. G.; LYONS, D. W.; CLARK, N. N.; GAURAM, M.; NORTON, P. M. Emissions from nine heavy trucks fueled by diesel and biodiesel blend without engine modification. Environmental Science and Technology, v. 34, p. 933-939, https://doi.org/10.1021/es981329b, 2000. 
YU, L.; GE, Y.; TAN, J.; HE, C.; WANG, X.; LIU, H.; ZHAO, W.; GUO, J.; FU, G.; FENG, X.; WANG, $X$. Experimental investigation of the impact of biodiesel on the combustion and emission characteristics of a heavy duty diesel engine at various altitudes. Fuel, v. 115, p. 220-226, https://doi.org/10.1016/j.fuel.2013.06.056, 2014. 